\title{
Information Technology Education Policy Framework for Developing Countries: Survey and Cluster Analysis of Worldwide Patterns in Information Technology Education
}

\author{
Martiniano Jake Parawan Neri III \\ Cagayan de Oro College-PHINMA Education Network \\ Cagayan de Oro City, Philippines
}

docachmed@gmail.com

\begin{abstract}
The paper examines worldwide patterns of operations of IT education using 31 countries' data on IT education focusing on contexts, inputs, processes and outcomes of IT education with the endin-view of deriving sets of national policies for IT education in the Philippines. In all, 13 variables were used as multivariate inputs to a cluster analysis algorithm which aim to cluster countries in terms of a $13 \times 13$ similarity matrix utilizing a hierarchical cluster method. Data per variable needed in the cluster analysis were obtained from the internet in most of the countries identified. Results revealed that developing countries' IT education differed from the IT education of developed and less developed countries in terms of: Contexts (Level of Development, Economic Basis, Educational System), Input (Percent of IT Professionals, National Literacy Rate, Percentage of Universities offering IT Courses), Process (Nature of Tertiary level Curriculum, Number of Years of exposure to IT, Provision of OJT in the curriculum, Instructional system, Admission status of IT courses), Output (Level of IT specialization), and Outcome (Employment status). On the basis of the hierarchical cluster analysis performed, policy recommendations are given to enhance the delivery of IT education in the Philippines and to sharpen its contribution to national development.
\end{abstract}

Keywords: IT education, context, inputs, process, outcomes, policy framework, cluster analysis, hierarchical method

\section{Introduction}

The global practices in the training of highly employable Information Technology (IT) Professionals vary in many ways. Some countries produce professionals that have been identified accordingly with the IT Infrastructure/services dominantly produced by major software and hard-

Material published as part of this publication, either on-line or in print, is copyrighted by the Informing Science Institute. Permission to make digital or paper copy of part or all of these works for personal or classroom use is granted without fee provided that the copies are not made or distributed for profit or commercial advantage AND that copies 1) bear this notice in full and 2) give the full citation on the first page. It is permissible to abstract these works so long as credit is given. To copy in all other cases or to republish or to post on a server or to redistribute to lists requires specific permission and payment of a fee. Contact 0HPublisher@InformingScience.org to request redistribution permission. ware industries as a strategic location for the best global reach. Others earn their training from distinguished professors, IT professionals, and faculty hired by the education institution. Accordingly, educational practices in tertiary education are readily observable in how they train these professionals that use and manipulate these IT infrastructures. It is generally a practice to rely on and refer to affiliating IT companies as au- 
thorities to define the level of expertise on how the individual use and manipulate their products/software. This practice is called certification, a series of assessments that usually works in two steps: 1.) Trainees study the theoretical foundations of a specific IT concept or software and master its functional use, and 2.) A diagnostic test both in written and practical aspects is performed in specially designed testing centers, where awards are usually given according to the level or category of expertise a candidate has achieved ranging from basic, intermediate, or expert. This certification can then be used to give a prospective employer, a bird's eye view of the level of expertise a candidate or applicant has for his/her disposal.

The Philippines has a commission of the same purpose, the Professional Regulation Commission (PRC). This is a state-authorized office that certifies professionals such as public accountants and nurses. However, it has not been able to create standardized tests for Information Technology graduates. While this commission has an indirect and sparse influence on the content of the Philippine Educational Curriculum in various fields due to these board exams, the IT educational system relies predominantly on the Commission of Higher Education's (CHED) findings from the technical panel that mandates the content according to industry needs and trends. These are patterned after the Association of Computing Machinery's (ACM) Computing Curricula Report of 2005, resulting in the creation of CHED Memorandum (CMO) 25, s2001 and the updated CMO 53 s2006 as policies and standards in information technology education. These cover the curricula of BS Information Technology, BS Information Systems and BS Computer Science, while a distinctly unique CMO 13 s2008 was created to cater to BS Computer Engineering majors.

The study explores the effects of variables grouped as context, input, process, output, and outcome, and its effect on the IT professional. Exploratory data mining procedures and techniques were used to analyze the data gathered from global counterparts in information technology education.

Findings showed that:

1. A mixture of variables under the context, input, process and output factors has diverse effects on the employability of IT professionals.

2. There are unusual observations. It is found out that countries with a history within the last 100 years of totalitarian rule tend to be consistent producers of highly employable IT professionals. It may also be due to the innate disciplinary attributes practiced as a way of life that help mold the training atmosphere of these ITE institutions.

3. A software conglomerate, Microsoft, developed an operating system (OS) of scalable stability with profitable price. After careful study, it identified countries with underdeveloped or developing IT infrastructure to be recipients of special OS software they labeled as "starter kits" at a lower price and operational limitations. This grouping confirmed the effect of the limited presence of IT infrastructures in these countries as minor influence for student's interest to study IT as a profession. This, in turn, will shape a poor image of IT graduates from that country.

4. Professionals from African or Asian decent, as well as the European and American counterparts, have a variety of effects in the employability of IT professionals from this perspective. While Asian and African nations take substantial effort in providing basic needs for the populace, their European and American counterparts are already maximizing their global dominance in the communication and computing economic venture. Such paradigm defines the image of IT professionals, considering government support priority projects in manpower development. 


\section{The Philippine IT Curriculum}

The current tertiary education system in the Philippines is currently governed by the policies mandated by the Commission on Higher Education (CHED). The Commission sets the minimum standard for any private institution to provide higher learning for the students. Each institution is required to secure a permit to operate, and later, to acquire government recognition. This recognition actually makes private tertiary institutions at par with state colleges and universities (SUC's). The standards implemented by the Commission are based on the state's mandate to safeguard the welfare of the higher education system. Part of the Commission's duty is to look for ways to improve the curricular offerings of higher learning institutions.

The Information Technology curriculum has been existent for quite some time. The rapid pace in the development of technologies phases out the standard curriculum set by the commission. A technical committee composed of industry practitioners and experts, along with curriculum specialists, are set up to fully analyze and formulate an updated curriculum that is responsive to the community and the industry, providing greater opportunities for graduates in terms of employment. The Commission sets up the policies and standards (PS) to provide the minimum standards for HEIs in providing quality education. These PS promote the HEIs' innovativeness in the formulation and the deployment of their program in their specific institutions. Information Technology may be a relatively young curricular offering, but it has undergone a major change by virtue of CHED Memorandum Order 53 (CMO \# 53), segregating the Information Technology profession into three (3) majors: the BS Information Technology, BS Information Systems, and the BS Computer Science. Each of these majors is distinct and unique, while remaining in harmony with the national goals for development.

Before this came into existence, the original structure of the Philippine ITE was framed after CMO 25, series of 2001. Its revision to its current state is the product of the upgrades made by the Commission to further enhance the delivery of IT education, set by a technical panel composed of personalities from all walks of the profession, both in the academe and the industry. Another CMO worth mentioning is the distinct curricula for IT engineering (CMO \# 13, 2008). The ITE courses and their basic descriptions are as follows:

1. Bachelor of Science in Computer Science (BSCS) - the study of concepts and theories, algorithmic foundations, implementation and application of information and computing solutions. The Bachelor of Science in Computer Science program prepares students to be IT professionals and researchers, and to be proficient in designing and developing computing solutions.

2. Bachelor of Science in Information Technology (BSIT) - the study of utilization of computers and computer software to plan, install, customize, operate, manage, administer and maintain information technology infrastructure. The Bachelor of Science in Information Technology (BSIT) program prepares students to be IT professionals, be well versed on application installation, operation, development, maintenance and administration, and familiar with hardware installation, operation, and maintenance.

3. Bachelor of Science in Information Systems (BSIS) - the study of design and implementation of solutions that integrate information technology with business processes. The BSIS replaces the Bachelor of Science in Information Management (BSIM) program. The Bachelor of Science in Information Systems (BSIS) program prepares students to be IT professionals and be expert on design and implementation of IS for business processes.

Information Technology Education (ITE) is built upon a core of courses and a series of professional courses leading to one or more of the three programs. The New General Education Curriculum as mandated by the Commission forms part of the requirements for ITE. The required 
natural science courses in the General Education curriculum include a laboratory component. The curriculum outline is divided into five (5) components namely: General Education, Basic ITE Core Courses, ITE Professional Courses, ITE electives and free electives with a minimum requirement of 140 units. The outline is as follows:

Language and Humanities
Mathematics, Natural Science and Technology
Social Sciences and Communication
Basic ITE Core Courses
IT Professional Courses
IT Electives
Free Electives
PE and NSTP

24 units

15 units

15 units

18 units

33 units

12 units

9 units

14 units

140 units

Thesis and Capstone projects are required for both BSIT and BSIS as a scholarly work of scientific approach with contents and concepts focused on computing. These studies may be presented in public forum. Internship is also required of all majors. It is an immersion program wherein the student will have the opportunity to be in the IT industry. This program is important because the students will have the chance to apply the skills, knowledge and attitude learned in the school and at the same time the opportunity to experience the corporate environment. Learning expectations in the IT related field should be established between the HEI and the industry in the form of a Memorandum of Agreement (MOA) or Memorandum of Understanding (MOU). Internship is a requirement for the BSIT and BSIS program but optional for the BSCS program. Students are eligible to enroll in the internship program after completing the $80 \%$ of the total number of units in the curriculum. The minimum number of internship hours for the BSIT and BSIS programs are 286 and 162 for the BSCS program (see complete details on CMO \#53 at www.ched.gov.ph/policies/index.html).

Another notable thing to mention is the thrust of the Commission of Information and Communications Technology (CICT) focus on Human Capital Development. This is relatively adding teeth/strength to the policies of both CHED and Department of Education (DepEd) in coming up with affiliated programs to increase awareness of the available IT tools locally seen for consumers to use. These programs are channels to increase user appreciation of IT with hopes to trigger IT enthusiasm in the youth. The human capital in these programs initiated by the government links additional social courses in college and university programs.

\section{Research Design}

Figure 1 shows the logical framework of the study. The study is based on the premise of the Context, Input, Process and Output as factors in influencing the outcomes of the Information Technology Profession. Each factor has corresponding variables that define its effect on the profession. For Context, we look at the level of development of the surveyed countries, as well as the basis in which their economies are made of, and the educational system that shape the tertiary level of learning. For Inputs, the study looks at the percentage of IT professionals in comparison to other professions (e.g. accountancy, teaching), as well as the national working literacy, and the percentage of Higher Educational Institutions with IT-related courses in their program offerings. The Process looks into the nature of HEI's administration, as well as the time a student is exposed to IT as a subject. It also looks at the provisions of On-the-Job training in the curricula, the implementation of their instructional systems, and their practices regarding the acceptance of applicants into their program. The Output focuses on the specialization or certifications issued to 
graduates who finish the program, while the Outcome measures how employable the graduates are.

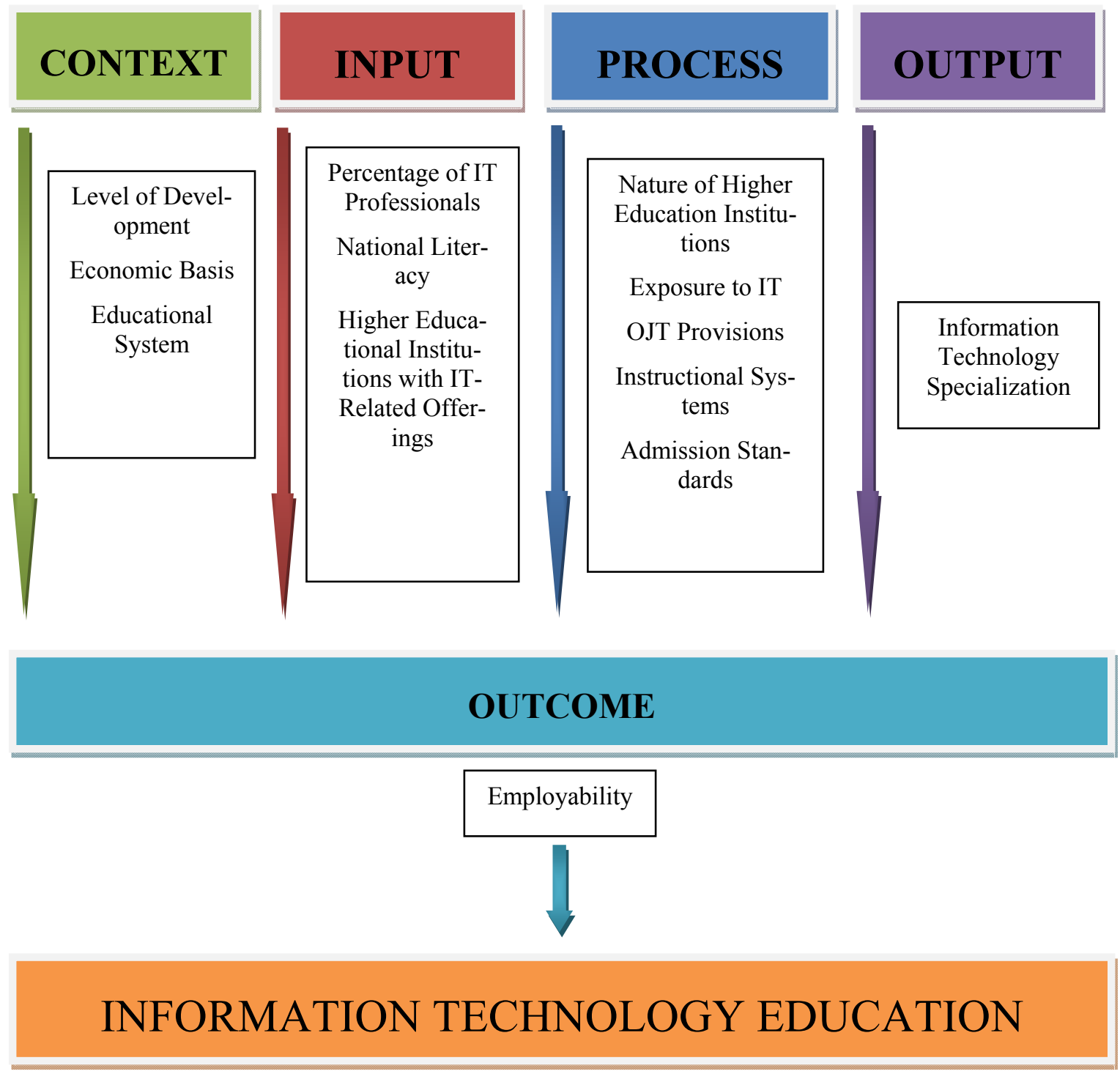

Figure 1: Logical Framework of the Study

In general, this study aims to analyze the present curriculum for Information Technology in the Philippines in comparison with the curriculum practiced by affiliate programs globally. It will also generalize the position of the Philippine IT curriculum along with the rest of the world.

The specific objectives are as follows:

1. Collate data on IT curricula from different institutions worldwide. Determine the position of the quality and standard of the said curriculum in a scale;

2. Identify and cluster the countries at par with the Philippines' IT Curriculum, as well as countries behind and ahead;

3. For countries that are behind the Philippines - state the details for the presumption of the superiority of the National IT Curriculum. For countries at par - state the details of the levels of equality, as well as the reason for such rating. For countries ahead - identify 
why the said country's curriculum is superior and identify also the lacking policies and practices that would help in the improvement of the IT curriculum; and,

4. Provide policy suggestions/recommendations for a responsive curriculum to the Commission on Higher Education.

The study looked at the factors that might have a noteworthy effect to the outcome of the IT profession. The outcome is a variable we identified as the employability of its graduates. Measures are designed in such a way that countries surveyed will be reliably identified according to the practices it exercised. Context, as defined, are the circumstances or events that form the environment wherein something exists or take place. Under this definition, we identified a country's development level, which is measured by the global Gross National Product (GNP) rank. The overall ranking, as defined by Microsoft Encarta 2008, assumes that the bottom 1/3 is considered underdeveloped, the middle $1 / 3$ is considered developing, and the upper $1 / 3$ is developed economies. The basis of primary economic exports of the countries surveyed is also identified. The data from the educational systems present in the surveyed countries show the extent of government and private controls over institutions. Data from the variable is identified to the ration of government controlled HEIs to privately-controlled ones. Like the first variable, each level of measure is represented by thirds of the entire population.

Inputs are things that enter a situation from the outside and then are acted or integrated upon. We identified the presence of IT as a profession and its composition in the labor pool. High values are identified with the IT professionals as exported manpower, medium values as professionals actively serving in the IT industry locally, while low values indicate the high incidence of unemployed IT professionals. National literacy is a figure published annually by the United Nations Educational, Scientific, and Cultural Organization (UNESCO), while HEI ratios of IT as a collegiate offering to other courses represent the number of institutions in a country that practice such.

The Process factor is guided by the idea that there are series of actions directed towards a specific aim. These actions include the nature of HEI's, whether specialized or generic curriculums are used, exposure to information technology, (measured in number of years prior to college), and counting computer literacy courses present in basic education. On-the-job provisions look into the official amount of time rendered by a student to compliment this activity as an academic requirement. The instructional systems are represented by the heavy presence of practical exercises, another value for more theoretical approaches in learning, and another for a well-balanced program. The admission statistics look on how many applicants are rejected or denied acceptance to the IT program.

The Output factor defines the production or yield, which is identified by an affiliated certification or specialization awarded to gradates of the program.

Table 1 presents the variables used and their description: 
Table 1: Description and Numerical Assignments of the Variables

\begin{tabular}{|c|c|c|c|c|}
\hline FACTOR & Variables & Description & Values & $\begin{array}{l}\text { Numerical } \\
\text { Assignment }\end{array}$ \\
\hline \multirow{10}{*}{ 站 } & \multirow{3}{*}{$\begin{array}{l}\text { Level of } \\
\text { Development }\end{array}$} & \multirow{3}{*}{$\begin{array}{l}\text { A country's level of } \\
\text { Development, in GNP } \\
\text { Rank }\end{array}$} & Developed & 1 \\
\hline & & & Developing & 2 \\
\hline & & & Under Developed & 3 \\
\hline & \multirow{4}{*}{ Economic Basis } & \multirow{4}{*}{$\begin{array}{l}\text { The primary produce of } \\
\text { the country the define } \\
\text { their economic } \\
\text { strength/export }\end{array}$} & Technology Based & 1 \\
\hline & & & Industrial & 2 \\
\hline & & & Manpower & 3 \\
\hline & & & Agricultural & 4 \\
\hline & \multirow{3}{*}{$\begin{array}{l}\text { Educational } \\
\text { Systems }\end{array}$} & \multirow{3}{*}{$\begin{array}{l}\text { Who operates and } \\
\text { administers the majority } \\
\text { of higher educational } \\
\text { system }\end{array}$} & Public & 1 \\
\hline & & & Combination & 2 \\
\hline & & & Private & 3 \\
\hline \multirow{5}{*}{$\frac{5}{5}$} & \multirow{3}{*}{ IT Professionals } & \multirow{3}{*}{$\begin{array}{l}\text { The ratio of the } \\
\text { country's population } \\
\text { with IT Institutions and } \\
\text { Courses }\end{array}$} & High & 1 \\
\hline & & & Medium & 2 \\
\hline & & & Low & 3 \\
\hline & $\begin{array}{l}\text { National } \\
\text { Literacy }\end{array}$ & $\begin{array}{l}\text { National adult working } \\
\text { literacy: basically read } \\
\text { and write }\end{array}$ & Varied & $0-100 \%$ \\
\hline & $\begin{array}{l}\text { HEl's with IT } \\
\text { Programs }\end{array}$ & $\begin{array}{l}\text { Institutions with IT as } \\
\text { part of a curricular } \\
\text { offering }\end{array}$ & Varied & $0-100 \%$ \\
\hline \multirow{11}{*}{ 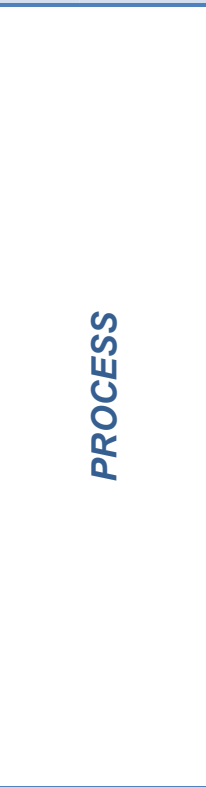 } & \multirow[b]{2}{*}{ Nature of HEl's } & \multirow{2}{*}{$\begin{array}{l}\text { The nature of the } \\
\text { subjects or courses in a } \\
\text { program }\end{array}$} & Specialized & 1 \\
\hline & & & Generic & 2 \\
\hline & Exposure to IT & $\begin{array}{l}\text { The exposure of the } \\
\text { technology as a subject } \\
\text { prior to tertiary } \\
\text { education }\end{array}$ & Number of Years & $1-10$ \\
\hline & \multirow{4}{*}{ OJT Provisions } & \multirow{4}{*}{$\begin{array}{l}\text { The extent of time a } \\
\text { trainee has to serve } \\
\text { before a degree is } \\
\text { awarded }\end{array}$} & $>18$ months & 1 \\
\hline & & & 13-18 months & 2 \\
\hline & & & 6-12 months & 3 \\
\hline & & & $1-5$ months & 4 \\
\hline & \multirow{3}{*}{$\begin{array}{l}\text { Instructional } \\
\text { Systems }\end{array}$} & \multirow{3}{*}{$\begin{array}{l}\text { Nature of teaching } \\
\text { methods }\end{array}$} & More Practical Apps & 1 \\
\hline & & & Combined & 2 \\
\hline & & & More Lecture & 3 \\
\hline & $\begin{array}{l}\text { Admission } \\
\text { Statistics }\end{array}$ & $\begin{array}{l}\text { Percent of applicants } \\
\text { denied acceptance to } \\
\text { the program }\end{array}$ & Varied & $0-100 \%$ \\
\hline \multirow{2}{*}{ OUTPUT } & \multirow{2}{*}{$\begin{array}{l}\text { IT } \\
\text { Specialization }\end{array}$} & \multirow{2}{*}{$\begin{array}{l}\text { Specializations } \\
\text { identified with the } \\
\text { graduate }\end{array}$} & High & 1 \\
\hline & & & Low & 2 \\
\hline \multirow{3}{*}{ OUTCOME } & \multirow{3}{*}{ Employability } & \multirow{3}{*}{$\begin{array}{l}\text { Waiting time before } \\
\text { employment }\end{array}$} & $\operatorname{High}(<6$ mo.) & 1 \\
\hline & & & Medium (7-12 mo.) & 2 \\
\hline & & & Low (>1 year) & 3 \\
\hline
\end{tabular}


This study is anchored on the premise that variances in contexts, inputs, processes, outputs and outcomes of IT education in different universities in various parts of the world are attributable to the varying national perspectives held by the countries' leadership in IT education. Ultimately, such national perspectives are motivated by mainly economic, social or political considerations in pursuit of the collective ideals of the nations. The nations' differential characteristics in terms of inputs, processes, outputs and outcomes of graduate education will, therefore form natural bases with which to cluster or group the countries. To this end, the study utilized the descriptive analytical method of research, extensively utilizing the method of cluster analysis (Padua, Lerin, \& Tumapon, 2007).

The term cluster analysis (first used by Tryon, 1939) encompasses a number of different algorithms and methods for grouping objects of similar kind into respective categories. A general question facing researchers in many areas of inquiry is how to organize observed data into meaningful structures, that is, to develop taxonomies. In other words, cluster analysis is an exploratory data analysis tool which aims at sorting different objects into groups in a way that the degree of association between two objects is maximal if they belong to the same group and minimal otherwise. Given the above, cluster analysis can be used to discover structures in data without providing an explanation/interpretation. In other words, cluster analysis simply discovers structures in data without explaining why they exist (Padua et al., 2007).

We deal with clustering in almost every aspect of daily life. For example, a group of diners sharing the same table in a restaurant may be regarded as a cluster of people. In food stores, items of similar nature, such as different types of meat or vegetables are displayed in the same or nearby locations. There are countless numbers of examples in which clustering plays an important role. For instance, biologists have to organize different species of animals before a meaningful description of the differences between animals is possible. According to the modern system employed in biology, man belongs to the primates, the mammals, the amniotes, the vertebrates, and the animals. Note how in this classification, the higher the level of aggregation, the less similar the members are in the respective class. Man has more in common with all other primates (e.g., apes) than it does with the more "distant" members of the mammals (e.g., dogs), etc. (Padua et al., 2007).

\section{Results and Discussions}

Data on the thirteen variables obtained through data mining and correspondences with key informants from the thirty one (31) countries involved in the study were subjected to cluster analysis using the (weighted) average hierarchical cluster algorithm with in order to group theses countries into three (3) clusters, each having distinct characters from others. Figure 2 shows the resulting dendogram. 


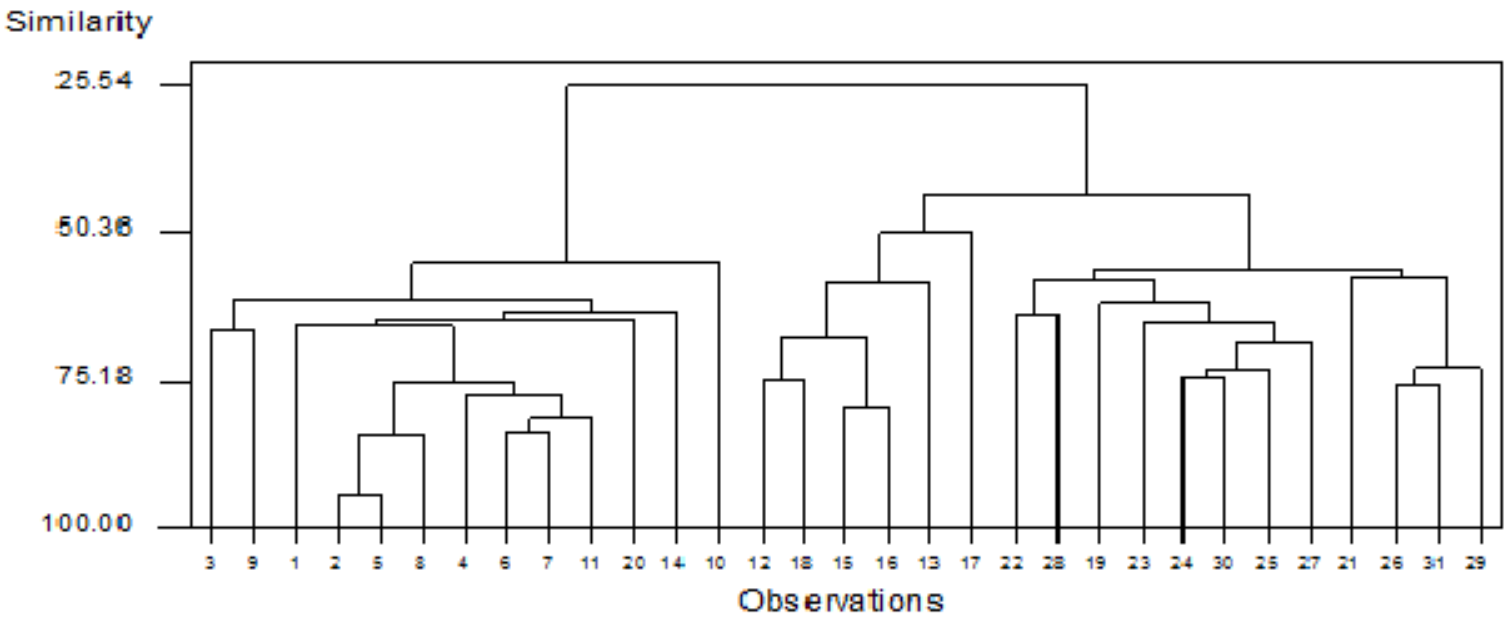

Figure 2: Dendogram of Thirty one (31) Countries

These clusters shown in Table 2 with 13 countries belonging to cluster 1, Six (6) in cluster 2 and Twelve in cluster 3. Countries belong to the same cluster are more homogenous in terms of the context variables considered than countries belonging to other clusters. The countries which belonged to each cluster are also shown in the same table. It may be noted that the Philippines is found in cluster 2 in the same league as Vietnam, Cuba, Ecuador, Costa Rica, and Cyprus. The available data highlights the level of development and the presence of private HEIs as dominant tertiary program providers. The United States is located in cluster 1 together with Romania, Canada, Malaysia, Ireland, Norway, UK, France, Germany, Japan, Australia, Sweden and Poland. The third cluster contains the following countries: CAR, Angola, Bangladesh, Nigeria, Kenya, Laos, Guatemala, Yemen, Uganda, Rwanda, Zimbabwe, and the Dominican Republic.

Table 2: Clustering of Countries based on the Cluster Algorithm

Number of Clusters: 3

\begin{tabular}{|c|c|c|c|c|}
\hline CLUSTER & $\begin{array}{c}\text { Number of } \\
\text { Observation }\end{array}$ & $\begin{array}{c}\text { Within Cluster } \\
\text { sum of Squares }\end{array}$ & $\begin{array}{c}\text { Average } \\
\text { Distance from } \\
\text { Centroid }\end{array}$ & $\begin{array}{c}\text { Maximum } \\
\text { Distance from } \\
\text { Centroid }\end{array}$ \\
\hline Cluster 1 & 13 & 9144.923 & 24.99 & 40.017 \\
\hline Cluster 2 & 6 & 8197.833 & 31.491 & 69.329 \\
\hline Cluster 3 & 12 & 16370.833 & 34.871 & 53.178 \\
\hline
\end{tabular}

Cluster 1: Romania, USA, Canada, Malaysia, Ireland, Norway, UK, France, Germany, Japan, Australia, Sweden and Poland

Cluster 2: Vietnam, Cuba, Ecuador, Costa Rica, Philippines, Cyprus

Cluster 3: CAR, Bangladesh, Angola, Nigeria, Kenya, Laos, Guatemala, Yemen, Uganda, Rwanda, Zimbabwe, and the Dominican Republic

Cluster 1 countries are grouped accordingly, but are not limited to: 1.) Highly developed economies, with GNP's belonging to the upper $1 / 3$ rd of the global GNP ranking, 2.) Technology-based 
or Industrialized products define more than half the in their national export, and, 3.) Highly visible IT professionals working in the IT Industry. These countries also manifest high literacy rates reported. Cluster 2 countries, where the Philippines and five other countries are grouped, evidently contain developing economies, combined educational systems, and high national literacy's. They are also exporters of skilled human resources. Cluster 3, on the other hand, are grouped with 11 countries that struggle with underdeveloped economies, amid IT programs with short OJT exposures. They usually train with lecture-type instructions even on technical courses, and are usually agriculture-based economies. These findings are summarized in Figure 3.

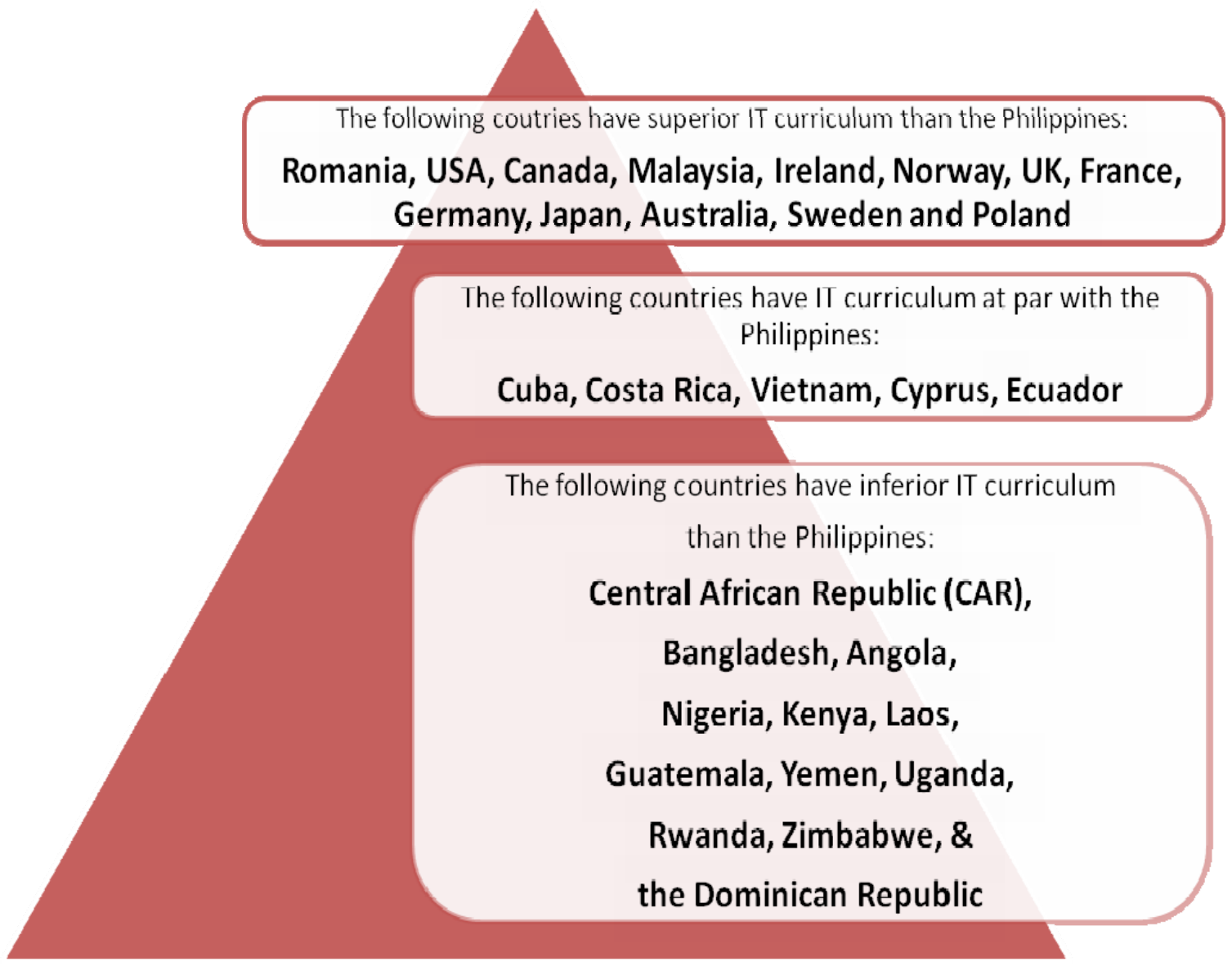

Figure 3: Scale of Comparison of the surveyed IT curricula

\section{Findings and Theory Generation}

\section{Policy Variables}

We next examined the variables used for contexts, inputs, processes and outputs of IT education in the various clusters to explain the IT education outcomes noted. Table 4 shows the centroids (weighted averages) of the aforementioned variables per cluster. 
Table 4. Centroids of Policy Variables by Cluster

\begin{tabular}{|c|c|c|c|c|c|}
\hline \multicolumn{6}{|c|}{ Cluster Centroids } \\
\hline & Variable & Cluster 1 & Cluster 2 & Cluster 3 & $\begin{array}{l}\text { Grand } \\
\text { Centroid }\end{array}$ \\
\hline \multirow{3}{*}{ Context } & $\begin{array}{c}\text { Level of } \\
\text { Development }\end{array}$ & 1.0769 & 2.0000 & 2.6667 & 1.8710 \\
\hline & Econ Basis & 1.7692 & 3.5000 & 2.6667 & 2.8387 \\
\hline & Educational System & 1.0769 & 1.8333 & 2.6667 & 1.8387 \\
\hline \multirow{3}{*}{ Input } & $\begin{array}{c}\%, \text { IT } \\
\text { Professionals }\end{array}$ & 1.4615 & 2.5000 & 3.0000 & 2.2581 \\
\hline & National Literacy & 98.3077 & 95.6667 & 69.0000 & 86.4516 \\
\hline & HEI with IT Prog & 63.2308 & 74.0000 & 41.2500 & 56.8065 \\
\hline \multirow{5}{*}{ Process } & Nature of HEI & 1.000 & 2.0000 & 2.0000 & 1.5806 \\
\hline & Exposure to IT & 8.5385 & 7.6667 & 4.6667 & 6.8710 \\
\hline & OJT Provisions & 1.5385 & 2.5000 & 3.4167 & 2.4513 \\
\hline & Instructional Systems & 1.3846 & 2.1667 & 2.6667 & 2.0323 \\
\hline & Admission Stat & 69.8462 & 51.1667 & 56.3333 & 61.0000 \\
\hline Output & IT Specialization & 1.0769 & 1.3333 & 2.0000 & 1.4839 \\
\hline Outcome & Employability & 1.2308 & 1.8333 & 2.8333 & 1.9677 \\
\hline
\end{tabular}

\section{Context}

Cluster 1 countries have developed economies that cater to an industrialized market in technology and electronics, while cluster 2 and 3 countries are either less developed or underdeveloped economies with agriculture as a way of living. This scenario allows maximum students' participation through OJT in available IT industries. A state's development in IT infrastructure directly influences the IT educational system, where students are allowed to participate in the operation of the industry as potential employees. The state-controlled educational systems in cluster 1 countries tend to have greater ties with industry partners, allowing these partners to define a specific part of their curriculum as a response to the needs of the company with relation to employee skills, compared to educational systems in countries from clusters 2 and 3 where major control is placed on private institutions.

Incidentally, agricultural countries in clusters 2 and 3 lack the much-needed IT facilities that could define their economic development.

Theory 1: As the level of development of a country increases, the employability of the IT graduates also increases. These countries have numerous semi-private HEls with exports of Industrial Materials and Manpower skills.

\section{Inputs}

Cluster 2 and 3 countries have very low number of IT professionals employed among their country's total employed professionals, while cluster 1 countries have competitive ratios with other fields of employment. Consequently, the national literacy rates of countries from clusters 1 and 2 have similar rates (more than 94\% working literacy), an indicator that both clusters of countries have the capacity to learn the same type of specialization, dependent only on the number of IT professionals that will handle the learning process. Cluster 3 countries barely have an above average working literacy at $69 \%$. This could be explained, similar to the one above, by the small number of the nations' IT professionals training the new applicants.

Similarly, the percentages of Higher Educational Institutions (HEIs) in cluster 1 and 2 are similar, with numbers below cluster 2 percentage (74\%). Countries in cluster 1 have just above average 
numbers of HEI with IT and its allied fields as a course offering because educational institutions specialize in a specific expertise in IT. This practice delimits other HEI's offering of the same IT specialization, forcing other HEIs to strive to create a new reputation over a specialization of a new expertise. Cluster 3 countries, on the other hand, posted a below average number of IT courses in their general curricular offerings. The absences of IT offerings in collegiate institutions, as well as the absence of IT infrastructures and industries, limit the employment opportunities for highly competent IT professionals.

Theory 2: Educated IT professionals from HEls with IT courses produce highly employable graduates.

\section{Processes}

IT programs in cluster 1 countries, with high probability, practice a wide variety of curricular IT specializations through practical exposure and hands-on teaching styles. This teaching style allows industry partners, like IT companies and developers, to allow students to work on the actual, day-to-day activities of the company. Both cluster $2 \& 3$ countries practice a combination of lecture and hands-on styles. This teaching style trains a somewhat generic IT graduate, where students pass through the same type of curriculum as stated in a common standard set by a governing body, and are also trained with a delimited practical exposure time.

Data likewise revealed that students in cluster 1 and 2 countries have been exposed to the trends and contributions of the IT industry in a much earlier part of their life. Existence of telecommunication infrastructures, like cable TV, cellular technologies and internet concepts has been a way of life. Students appreciate IT as early as the start of secondary education (averaging 7 years including college). On the other hand, the third cluster countries only start to appreciate Information Technology concepts late in secondary education or just during college. Appreciation of IT based contributions usually influences applicant students to enroll in IT courses and its allied fields.

OJT exposures in affiliate industrial partners for cluster 1 countries make up a major part of the IT curriculum, with more than 18 months of industry immersion prior to the completion of the program. Cluster 2 countries $\log$ in an average of 6 to 12 months, usually 1 to 2 semesters. Cluster 3 countries have less than 6 months, or even an hourly basis. This exposure to the industry, coupled with a complimentary instructional system, is defining factors in the excellence of graduates. Most prominent employing IT companies usually look at the extent of the OJT program to assess the tuning of a candidate in his/her adjustment from schooling to employment. The records in the portfolios of logged time in the OJT program also strengthen the positive perceptions (experiences, actions taken on presented problems, administrator recommendations, etc.) of IT graduates with the prospective employers.

Admission standards (rejection rates) for cluster 1 countries stand at around $30 \%$. This may be justified that even though the IT industries of highly developed countries are quite in need of employing expert IT professionals, they are also ensuring the employment of the best qualified graduates by allowing the HEIs' limited admission rules to control quality of graduates. Competitive admission requirements (high SAT scores, state admission policies) may define good quality of students taking up a course in a specific academic program. In countries of clusters 2 and 3, almost half of the applicants to IT programs move up to study the profession.

Theory 3: Generic HEls with mixed instructional system and moderately selective admission process produce highly employable IT graduates. IT exposures starting in basic education craft an employable IT graduate. An HEI with a strong theory, hands-on IT program and a compulsory year of OJT exposure contribute to the employability of an IT graduate. 


\section{Output}

The output indicator of IT education used in this study is the ratio of the level of specialization in IT to the employability in the IT industry. Data revealed that high specific IT specializations found in graduates of IT HEIs in cluster 1 countries tend to be very employable in IT industries (high specialization to high employment status) while employability is quite low for cluster $2 \& 3$ countries (generic specialization in average to low employment opportunities).

In sum, the study wishes to seek validation in the theory extracted from the study. It found out that:

Theory 4: As the level of specialization increases for ITE graduates, their employability also increases.

The survey found out that countries with developed economies have developed IT infrastructures in the industry in forms of Cellular, Networking, and Software technologies. These technologies are also accessible to the populace. The presences of these technologies also define the demand of specialists that would operate the hardware and operation system. It is also notable that graduates who specialize in the available IT infrastructure in their countries tend to easily find and job that compensates them well. We would also look into the specializations presented by the graduates through testing and certifications.

\section{Unusual observations}

Unusual patterns have always been a headache in data analysts. Some label this phenomenon as unusual observation outliers. It is very tempting to get rid of them to make a conclusion easier, but yet, we look for ways to use these occurrences in a more productive manner. Elimination of these instances is a shortsighted way to conclude, equivalent to ignoring our way out to meet our expectations, or disregard anything that violates our assumptions. We need to know why this behavior exists, and look for ways to understand and improve them. Sometimes, the outlier is an important discovery, such as a previously unknown feature of the relationship between variables.

First, we should check each unusual observation carefully. Let us clarify the underlying cause, that it should not be clerical in nature, such as typing 37.5 in place of 375 . We need to check the integrity of our data as soon as possible so that we can find out whether mistakes have been made. We correct our data to leave out false or incorrect numbers. If we are satisfied that an unusual observation is not a mistake, we need to ask whether this observation affects the results unduly. One way to determine this is to reanalyze the data with the unusual behavior omitted. This model will probably be better, since we removed the unusual part. But if the unusual observation makes a little difference whether it is in or out, it is best that we keep it intact. If it makes a major difference, we have to ask whether the model with the unusual observation omitted appears to fit the data well, wherein we can conclude that the model fits for all data except the unusual ones, and think out of the box why indeed they were unusual. If it still does not make sense, we need to try to describe the relationship in a different way.

\section{Discussion on the alternate theory for context}

In the context factor, observation 17 (Vietnam) came out as one of the unusual behavior outliners. Another observation, Romania, is also registered as an outlier. Both countries registered high employability in their graduates and are both in the developing phase. Both countries have combined educational systems visible in their IT curricula, with high literacy rates that provide basic skills that augment the economy. The practice of early IT exposure is visible in the basic educational subjects taken mandatorily by children and youth of the schooling age, and their tertiary IT educational programs produce highly specialized IT graduates and highly employable IT Professionals. 
Looking at the history and political structure of both countries, we find similarities in terms of the administration of the government for the last century, as both countries have past or present experiences under a totalitarian rule. This system of government manifests rigid respect \& obedience to commands and practices, especially those mandated by law and the state. This is plainly characterized by a government in which the political authority exercises absolute and centralized control.

Thus we came up with a new theory, stating:

\section{Alternate Theory 1: Other than the stated variables under the context factor, Employability of IT graduates is influenced by the practice of discipline in stated countries with histories of totalitarian rule.}

We then segregated the countries, with a column for countries with history of totalitarian rule within the last 100 years, and another column for countries practicing other forms of government.

Table 5: Validating the Context Alternate Theory

\begin{tabular}{|c|c|c|c|c|c|}
\hline Variable & $\mathbf{N}$ & Mean & StDev & $\mathbf{T}$ & Remarks \\
\hline Countries with history of totalitarian rule & 21 & 2.1 & .873 & & \\
\hline $\begin{array}{c}\text { Countries without history of totalitarian } \\
\text { rule }\end{array}$ & 10 & 1.5 & .527 & 2.73 & SIGNIFICANT \\
\hline
\end{tabular}

In Table 5, the observed t-value is 2.73 , which means that we have to accept the formulated theory that states that discipline learned from previous histories of totalitarian government has an influence in the employability of IT graduates. It may also be stated that the rigid training required of IT graduates is the underlying factor that defines the skill present in these graduates. It can also be surmised that if the government steps up to demand the skills required in the operation of available IT infrastructures as needed, their citizens are actually left with limited choices to deal with.

\section{Discussion on the alternate theory for Inputs}

We looked again at the characteristics of 4 (four) observations in terms of our input factor: Australia, Romania, Zimbabwe and Bangladesh. The diversity of these behaviors can be summarized by an action done by Microsoft, a software conglomerate, on the distribution of its operating system software. Microsoft found out that, as the sophistication of their software to guard against attacks rise, they need to beef up the coding systems to counter this threat. But the development is costly, and while they targeted certain countries for this development, other countries are no longer capable of purchasing it in full price. A revision of this software was made to fit the paying budget of these countries. Microsoft called this software the same name, only with the additional term 'starter', a limitation on how many processes are run at the same time. Only 139 countries were identified to sell this software. This move was welcomed by the IT community as a 'humanitarian act' and a way to prevent discrimination by interested buyers due to financial capacity. The operating software "Microsoft Windows XP" was available as "Microsoft Windows XP starter", while "MS Vista" was made available as "MS Vista starter". A list of the countries identified by Microsoft is used as a determining factor in the employability of IT graduates.

Starter software basically functions like the mother software it was patterned from, with limitations defined by hardware specs as defined in end-user license agreement (EULA). It is in this comparison that we formulate the trend of a learning process. The employability of an IT professional can be defined the capacity of the software he uses for study and mastery. If he is exposed to limited and restricted software, his learning might also be restricted or bound only within the capacity of what he is to experience by design. Moreover, it he gets greater access to more versatile software, with limits minimized and functionality increased, he will have ample opportunity 
to use it more for practice and mastery. Systems are designed these days to multitask, that is, to allow multiple streams of operations to run at different threads of information at the same time, increasing work efficiency and effectivity, as well as lesser energy consumption.

Then we formulated a theory and validated it using T-test. The results are as follows:

Alternate Theory 2: Markets identified by Microsoft for the starter edition software are countries with low employability of IT graduates, while for countries where the starter edition is not available, the employability of IT graduates are high.

\begin{tabular}{|c|c|c|c|c|c|}
\hline Variable & N & Mean & StDev & T-value & Remarks \\
\hline MS identified & 16 & 2.5 & 0.730 & \multirow{2}{*}{4.9} & SIGNIFICANT \\
\hline $\begin{array}{c}\text { Non-MS Iden- } \\
\text { tified }\end{array}$ & 15 & 1.4 & 0.507 & & \\
\hline
\end{tabular}

Table 6: Validating the Input Alternate Theory

As seen in Table 6, the tests showed the T-value of this segregation is at 4.9, making the grouping significant in its effect to the employability of the IT graduates. This statement accepts our proposed theory, and validates it through this statistical treatment. This is the same perspective seen by Microsoft in the deployment of available IT software to budget-conscious countries, in order for their citizens to appreciate the technology more. It is also notable that Microsoft faces a challenging battle against software piracy and the existence of open-source codes that match the capacities or functions of the software they are selling.

\section{Discussion on the alternate theory for process}

The third factor involves the process variables, and the following countries, namely, Vietnam, Zimbabwe, Malaysia, and Rwanda are the outliers. Basically, these countries are geographically located in the Asian and African region, and we use this information as a grouping to identify and formulate a theory from the unusual observations. We group countries according to origin, one group for Asian/African-identified countries and another group for countries not in the Asia/Africa Regions.

Table 7: Validating the Process Alternate Theory

\begin{tabular}{|c|c|c|c|c|c|}
\hline Variable & $\mathbf{N}$ & Mean & StDev & T-value & Remarks \\
\hline Asian/African & 17 & 1.52 & 0.514 & -3.73 & \multirow{2}{*}{ SIGNIFICANT } \\
\hline Non-As/Af & 14 & 2.5 & 0.855 & & \\
\hline
\end{tabular}

As shown in Table 7, the tabular results showed the influence of geographical location with a Tvalue of -3.73 . Therefore, we accept the theory that states:

Alternate Theory 3: Geographical locations in major country groups have varied effects on the employability of IT graduates.

This may be so, as countries not found in Asia and in Africa are forerunners of Information Technology through communication and computing. As Asian and African nations' economies struggle in their economies in feeding the populace, neighboring countries in Europe and America are already setting up trends to augment their economic strength in communication and computing technologies.

Summarized findings for theories presented showed that:

1. A mixture of variables under the context, input, process and output factors has diverse effects on the employability of IT professionals. 
Information Technology Education Policy Framework

2. There are unusual observations. It is found out that countries with a history within the last 100 years of totalitarian rule tend to be consistent producers of highly employable IT professionals. It may also be due to the innate disciplinary attributes practiced as a way of life that help mold the training atmosphere of these ITE institutions.

3. A software conglomerate, Microsoft, developed an operating system (OS) of scalable stability with profitable price. After careful study, it identified countries with underdeveloped or developing IT infrastructure to be recipients of special OS software they labeled as "starter kits" at a lower price and operational limitations. This grouping confirmed the effect of the limited presence of IT infrastructures in these countries as minor influence for student's interest to study IT as a profession. This, in turn, will shape a poor image of IT graduates from that country.

4. Professionals from African or Asian decent, as well as the European and American counterparts, have a variety of effects in the employability of IT professionals from this perspective. While Asian and African nations take substantial effort in providing basic needs for the populace, their European and American counterparts are already maximizing their global dominance in the communication and computing economic venture. Such paradigm defines the image of IT professionals, considering government support priority projects in manpower development.

\section{Conclusions}

The Philippines, as a developing nation, is constantly updating the trends of IT as a profession. What we lack in infrastructure is well compensated by our thrust towards remarkable training and ingenuity. Our IT graduates are competent enough to be certified with global IT authorities and we have been exporting a number of manpower to the profession worldwide. We are second only to India in providing support to IT industries through agent-based assistance.

The Filipino IT curriculum is safeguarded by the constitutional authority of the Commission on Higher Education, and is patterned after the updated report of IT professionals from the Association of Computing Machinery. Locally, the President's office instituted the existence of the Commission on Information and Communications Technology. This is a major step of the state's appreciation of the profession and this makes IT readily available for utilization for the general public. The commission spearheaded projects that define the IT infrastructure (Community ecenters), the development of the Human Capital (i-School), the participation in the business sector (cyber services corridor), and the governments' place in technology (eGovernment Portal).

Based on the objectives and findings of the study, the following conclusions are drawn:

1. The economic standard of a country is defined by its GNP ranking in the worldwide arena. As the country progresses, infrastructure in IT also exist to accommodate communications and computing.

2. Employment of IT graduates is also affected by the available IT infrastructure easily acquired by countries that produce them.

3. The balance between the public and private administration of HEIs is also essential to the development of highly employable professionals.

4. While some countries produce highly employable IT professionals with limited access to employment in their native countries, the demand for these professionals in the global setting is a promising venture for the professionals to undertake.

5. Literacy acquired through education has a major effect on the acquisition of skills that outline a highly competent IT professional. 
6. The Information Technology curricula is mainstreaming well with other courses offered in HEI's. Institutions need not be identified as a highly technical training institute, as long as they have the correct formula of experts and trainers that produce competent graduates.

7. A combination of theory and practical exposure define the right balance for an employable graduate.

8. Exposure to the industry, for at least 12 months, is essential for each graduate. OJT will attune their skills to what is needed in the industry, increasing employment opportunities.

9. A good start for HEIs to ensure quality in future IT manpower is to filter out applicants with insufficient background. This action will keep the right students in the program until graduation. The profession is highly technical by nature, and it needs individuals that are able to see this attribute as a need in the profession.

10. A definite path towards a specific specialization should be the goal of each graduate. This is to prevent redundant skills in the profession. The technology itself is evolving into a more distinct and a highly specialized profession.

\section{Policy Recommendations}

Analysis of the worldwide patterns for IT education revealed three distinct clusters of countries with the clustering mainly driven by the way their IT education outputs are being utilized to contribute to national economic development and by the countries' national perspectives on IT education. More economically developed nations tended to be clustered together while the developing and less developed nations were similarly clustered together. The study found out that the clustering of countries may actually be attributed to the differential characteristics of IT programs in these countries in terms of their contexts, inputs, processes and outputs. In view of these, the following policy recommendations are suggested for consideration by the Philippine Commission on Higher Education:

1. The Commission on Higher Education may facilitate the crafting and definition of a national vision for IT education outcomes similar to the clear and unequivocal national perspectives of developed nations, such as the USA. Such a national vision translates into institutional policies on admission, processes and outputs for IT education.

2. IT studies in HEIs should be fully administered by state controlled institutions to emulate the quality of graduates produced by HEI's in countries like the USA, Japan and Germany. In cases like the Philippines, where private institutions outnumber the State Universities and Colleges (SUCs), a standard quality mechanism, such as updated curriculums and International accreditations / certifications must be visible in SUCs for private HEIs to pattern. These benchmarks must compete with the highest international standards.

3. The short basic education cycle of the Philippine educational system forces its higher education system to compensate by providing for general education courses in college curricula which could otherwise have been used for specialized trainings. IT specialization courses, which presumably are highly focused, should therefore be made more intensive. To this end, early exposure to technological trends and developments needs to be encouraged in order to ensure high quality training of IT graduates. The state should continue to raise awareness of the available technologies the citizens could use, like cellular technology and the Internet. Likewise, specialized certification programs like CISCO or MS suites will have to be expanded and sustained in order to develop better equipped IT engineers and professionals to handle technologies in business and industry. 
4. In general, IT Education needs to be more selective in order for the country to benefit most out of its outputs. Information Technology is a highly technical profession, and it needs highly technical manpower to fully utilize its capacity and purpose.

5. Hands-on courses, especially in technical subjects, should be visible and well indoctrinated into the IT curriculum. Major subjects should already identify a student's direction early on his quest for expertise in the IT field. The formulation of a rigid and robust IT curriculum, complete with realistic approaches to technological advancement in learning, is a necessity for the Philippines' future IT graduates.

6. Distinct specialization curricula (IT Majoring), particularly in fields outside the CICSO certifications, need to be supported by establishing more such programs in selected IT schools in the country through special grants from industry partners. There are more than fifty specializations in the business market, each distinct and unique. It is also preferable to team up with the blooming call product-based support industry, and use their supervision of OJTs as grounds for certification/training.

7. The processes adopted by recognized IT schools in the Philippines need to be standardized in such a way that a certification is part of the process for a degree. As long as the Professional Regulation Commission cannot issue a board or licensure exam for IT graduates, certifications will be the quality control mechanism. Certification works in two ways: a) it verifies that the graduate is capable, and b) the providing institution is capable of producing a verified professional IT expert.

8. On-the-Job Trainings (OJTs) need to be treated not just as a mere appendage to IT programs but as a centerpiece of all technical programs. While the pressure to confer degrees in a shorter period of time may be quite strong, producing ill-trained graduates who cannot do productive work will, in the long run, be counterproductive to the Philippine IT education system.

9. A distinct specialization in IT should be the goal of each graduate. HEIs and SUCs should also be identified according to a specific IT specialization, complimentary in general IT courses, but unique in expertise in forms of specializations (e.g. networking, operation systems, quality control), product/brand affiliations (e.g. Unix, Suns Micro System, Delphi) and product certifications (e.g. MS VIP, Cisco, Java).

\section{References}

Asan, A. (2003). Computer technology awareness by elementary school teachers: A case study from Turkey." The Journal of Information Technology Education, 2, 152-164. Retrieved from http://jite.org/documents/Vol2/v2p153-164-109.pdf

Barbe, W. B., \& Swassing, R. H., with M. N. Milone. (1979). Teaching through modality strengths: Concepts and practices. Columbus, $\mathrm{OH}$ : Zaner-Bloser.

Blurton, C. (n.d.). New directions of ICT-use in education. Retrieved on 2007-02-06 from http://www.unesco.org/education/educprog/lwf/dl/edict.pdf

Bolt, M., Killough, L., \& Koh, H. (2001). Testing the interaction effects of task complexity in computer training using the social cognitive model. Decision Sciences, 32(1), 1-19.

Brookshire, R. (2000). Information technology certification: Is this your mission? Information, Technology, Learning, and Performance Journal, 18(2), 12-13.

Dillon, A., \& Gabbard, R. (1998). Hypermedia as an educational technology: A review of the quantitative research literature on learner comprehension, control, and style. Review of Educational Research, $68(3), 212-213$. 
Dixon, M., McGill, T., \& Karlsson, J. (1997). Using a network simulation package to teach the clientserver model. Proceedings of the Conference on Integrating Technology into Computer Science Education, 151-152.

Egnatoff, W. (n.d). Computers and lifelong learning. On-line Survey. January 15th, 2002

Livari, J., Hirschheim R., et al. (1998, June). A paradigmatic analysis contrasting information systems development approaches and methodologies. Information Systems Research, 9, 164-193.

Lunt, B., Helps, R., Lawson, E., \& Goodman, G. (2002). Designing an IT curriculum: The results of the first CITC conference. Proceedings of the 2002 American Society for Engineering Education Annual Conference \& Exposition.

McIntyre, D., \& Wolff, F. (1998). An experiment with WWW interactive learning in university education. Computers \& Education, 102-103.

Padua, R., Lerin, M., \& Tumapon T. (2007). Graduate education policy framework for developing countries: Survey And cluster analysis of worldwide patterns in advanced education. Liceo Journal of Research.

Paivio, A. (1971). Imagery and verbal processes. New York, NY: Holt, Rinehart, and Winston. (Reprinted 1979, Hillsdale, New Jersey: Erlbaum.)

Paivio, A. (1986). Mental representations: A dual-coding approach. New York: Oxford University Press.

Piccoli, G, Ahmad, R., \& Ives, B. (2001). Web-based virtual learning environments: A research framework and a preliminary assessment of effectiveness in basic IT skills training. MIS Quarterly, 25(4), 401426.

Potashnik, M., \& Capper, J. (1998). Distance education: Growth and diversity. Retrieved on 2007-02-06 from http://www.worldbank.org/fandd/english/pdfs/0398/0110398.pdf

Sneath, P. H. A., \& Sokal, R. R. (1973). Numerical taxonomy. San Francisco: Freeman.

Swassing, R. H., Barbe, W. B., \& Milone, M. N. (1979). The Swassing-Barbe modality index: Zaner-Bloser modality kit. Columbus, $\mathrm{OH}$ : Zaner-Bloser.

Taghioff, D. (2001). Seeds of consensus-The potential role for information and communication technologies in development. Retrieved on 2003-10-12 from

http://web.archive.org/web/20031012140402/http:/www.btinternet.com/ daniel.taghioff/index.html

Tyron, R. C. (1939). The growth of cluster analysis. Multivariate Behavioral Research, 15, 439-458.

\section{Biography}

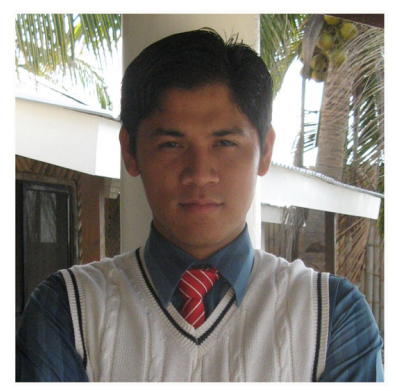

Martiniano Jake Parawan Neri III is an Assistant Professor at Cagayan de Oro College-PHINMA Education Network. His interest in Education and IT research and how these two areas can work together in harmony is a newfound fascination. He received his Ph.D. on Educational Planning and management from Mindanao University of Science and Technology earlier this year. He also keeps a sharp significance of attention with fellow researchers in the field of healthcare on ergonomics and healthy IT practices. He believes that his versatility to adapt is his greatest strength, and going through this, he relies on his two best girls, wife Deedee Donna and daughter Yajna Meggan, and on Siamese cats Mitzi and Thunder, his best de-stressers 